\title{
PENGARUH DOSIS ZEOLIT DAN PUPUK SP-36 TERHADAP KETERSEDIAAN P PADA LATOSOL DAN SERAPAN P PADI GOGO (Oryza sativa L.)
}

\section{(EFFECTS OF ZEOLITE AND SP-36 FERTILIZER DOSAGES ON THE AVAILABILITY OF P IN LATOSOL AND P UPTAKE OF UPLAND RICE (Oryza sativa L.))}

\author{
Fahmi Herwinastwan Prakosa $^{1)}$, R. Agus Widodo $^{2) *}$, dan Lelanti Peniwiratri ${ }^{3)}$ \\ ${ }^{1)}$ Prodi Agroteknologi, Universitas Pembangunan Nasional Veteran Yogyakarta \\ ${ }^{2)}$ Prodi Ilmu Tanah, Universitas Pembangunan Nasional Veteran Yogyakarta \\ ${ }^{*}$ Corresponding author E-mail: r_aguswid@upnyk.ac.id
}

\begin{abstract}
The limited availability of $\mathrm{P}$ becomes an obstacle to Latosol and it can be solved through the application of zeolite and SP-36 fertilizer. This study aims to identify the effect of zeolite and SP-36 fertilizer on the availability of $\mathrm{P}$ and the growth of gogo paddy. The research was conducted in the greenhouse of the Faculty of Agriculture of UPN Veteran Yogyakarta. This research used a completely randomized 2-factor design. The first factor, zeolite dose, consists of 3 levels: $0,2.5$, and 5 tons/ha. The second factor is SP-36 dose consisting of 3 levels equivalent to 0,50 , and $100 \mathrm{P}_{2} \mathrm{O}_{5} \mathrm{~kg} / \mathrm{ha}$. It obtained nine treatment combinations with three replications and it resulted in 27 pots. The soil analysis parameters consisted of $\mathrm{pH} \mathrm{H}_{2} \mathrm{O}, \mathrm{pH} \mathrm{KCl}, \mathrm{P}-$ available, Cation Exchenge Capacity, and the plant parameters were P-tissue and uptake P. To identify the effect of treatment, the data were analyzed with ANOVA and followed by DMRT of a 5\% level. The results showed that the application of zeolite significantly affected the $\mathrm{pH}_{2} \mathrm{O}$ Latosol, P-available Latosol, and P-tissue upland rice, but it did not significantly affect the Pabsorption of upland rice. The application of SP-36 significantly affected the P-available Latosol but did not significantly affect the $\mathrm{pH} \mathrm{H}_{2} \mathrm{O}$ Latosol, P-tissue, and P-uptake of upland rice. It can be said that the interaction of zeolite and SP-36 significantly affects the P-available and P-tissue. Zeolite equivalent to 5 tons/ha and SP-36 equivalent to $50 \mathrm{~kg} \mathrm{P}_{2} \mathrm{O}_{5}$ are the optimal doses to increase the growth of upland rice in Latosol.
\end{abstract}

Keywords: latosol, upland rice, SP-36 fertilizer, and zeolite

\begin{abstract}
ABSTRAK
Ketersediaan P yang rendah, menjadi kendala pada tanah Latosol. Hal ini dapat diatasi dengan pemberian zeolit dan pupuk SP-36. Penelitian ini bertujuan untuk mengetahui pengaruh perlakuan dosis zeolit dan pupuk SP-36 terhadap ketersediaan P dan serapan P padi gogo. Penelitian dilaksanakan di rumah kaca Fakultas Pertanian, UPN "Veteran" Yogyakarta. Penelitian ini menggunakan Rancangan Acak Lengkap 2 faktor. Faktor pertama dosis zeolit terdiri dari 3 aras: $0 ; 2,5 ; 5$ ton/ha. Faktor kedua dosis SP-36 terdiri 3 aras setara dengan: 0; 50; dan $100 \mathrm{P}_{2} \mathrm{O}_{5} \mathrm{~kg} / \mathrm{ha}$. Setiap kombinasi perlakuan diulang 3 kali, sehingga didapatkan 27 pot. Parameter analisis tanah terdiri $\mathrm{pH} \mathrm{H}_{2} \mathrm{O}, \mathrm{pH} \mathrm{KCl}, \mathrm{P}$ tersedia, dan $\mathrm{KTK}$ tanah, $\mathrm{P}$ jaringan dan serapan $\mathrm{P}$ padi gogo. Untuk mengetahui pengaruh perlakuan dengan sidik ragam (Anova) dan dilanjutkan dengan DMRT taraf 5\%. Hasil penelitian menunjukkan aplikasi zeolit berpengaruh
\end{abstract}


nyata terhadap $\mathrm{pH} \mathrm{H}_{2} \mathrm{O}$, P-tersedia Latosol dan P-jaringan padi gogo, tetapi tidak berpengaruh nyata terhadap serapan P padi gogo. Dosis SP-36 berpengaruh nyata terhadap P-tersedia, tetapi tidak berpengaruh nyata terhadap $\mathrm{pH}_{2} \mathrm{O}$ Latosol, P-jaringan dan serapan $\mathrm{P}$ padi gogo. Interaksi zeolit dengan SP-36 yang berpengaruh nyata meningkatkan P-tersedia dan P-jaringan. Zeolit setara 5 ton/ha dan SP-36 setara $50 \mathrm{~kg} \mathrm{P}_{2} \mathrm{O}_{5}$ merupakan dosis optimal untuk meningkatkan pertumbuhan padi gogo di Latosol.

Kata kunci : latosol, padi gogo, pupuk SP-36 dan zeolit

\section{PENDAHULUAN}

Kebutuhan bahan pangan terus meningkat sejalan dengan pertambahan jumlah penduduk. Untuk memenuhi kebutuhan tersebut maka perlu usaha peningkatkan produksi pertanian. Salah satu bahan pangan yang tengah dikembangkan ada penanaman padi Gogo. Padi gogo adalah varietas padi hasil pemuliaan yang dirancang agar tahan terhadap kondisi cekaman air atau kekeringan. Peningkatan produksi dapat dilakukan dengan cara mengoptimalkan faktor-faktor yang mempengaruhi pertumbuhan tanaman di antaranya adalah mengoptimalkan ketersediaan unsur hara dalam tanah.

Unsur P merupakan salah satu unsur hara esensial yang dibutuhkan dalam tanaman dalam jumlah yang banyak. Unsur ini digunakan tanaman untuk pembentukan protein terutama dalam transfer metabolik adenosine triphosphate (ATP), fotosintesis dan respirasi, selain itu, peranan fosfor lainnya dalam pembentukan akar, mempercepat pembungaan, mempercepat matangnya buah, dan memperkuat tubuh tanaman (Rismunandar, 1990). Tanaman menyerap unsur hara P dan bentuk orhofosfat. Sebagian besar pupuk $\mathrm{P}$ diaplikasikan akan menjenuhi kapasitas jerapan P. Hasil penelitian menunjukkan bahwa hanya $10-20 \% \mathrm{P}$ yang diaplikasikan tersedia untuk serapan tanaman, sedangkan sisa $\mathrm{P}$ tanah (residu P) teradsorpsi pada konstituen tanah ( A'isyah et al., 2019).

Nama latosol diusulkan pertamakali oleh Kellog (1949) bagi golongan tanah yang meliputi semua tanah zonal didaerah tropis dan khatulistiwa yang memiliki sifat-sifat dominan: 1. Nilai $\mathrm{SiO}_{2}$ (silika) fraksi lempungnya rendah 2. Lempungnya kurang aktif 3. Kadar mineral rendah. Latosol meliputi tanah-tanah yang telah mengalami pelapukan intensif dan perkembangan tanah lanjut sehingga terjadi pelindian unsur basa, bahan organik dan silika sebagai sisa berwarna merah. Memiliki kandungan mineral primer dan unsur hara yang rendah, memiliki pH yang rendah yaitu 4,5-5,5.16 (Darmawidjaja, 1990). Rendahnya jumlah basa-basa dapat dipertukarkan seperti $\mathrm{Ca}, \mathrm{Mg}, \mathrm{K}$, dan $\mathrm{Na}$, tanah bersifat masam, rendahnya kadar bahan organik karena cepat terdekomposisi serta melepaskan basa-basa dalam senyawa organik yang merangsang pelarutan silika dan pelarutan $\mathrm{Fe}$, Al, dan Mn yang dapat mengakibatkan keracunan bagi tumbuhan. Kationkation basa merupakan unsur hara yang diperlukan tanaman. Kemampuan pertukaran kation yang rendah pada tanah ini disebabkan oleh kurangnya bahan organik tanah dan sifat hidrat oksida.

Berdasarkan permasalahan di atas, maka perlu adanya usaha untuk meningkatkan unsur hara $\mathrm{P}$ tersedia agar pertumbuhan tanaman dapat mencapai optimal. Kekurangan unsur P pada padi akan menyebabkan pertumbuhan perakaran dan tanaman terhambat, jumlah anakan berkurang, lebar daun berkurang, produk asimilat berkurang, waktu berbunga lebih lambat, banyak gabah hampa, dan penurunan jumlah gabah per malai. 
Pada umumnya permasalahan kekahatan $\mathrm{P}$ pada tanaman diatasi dengan memberikan pupuk SP-36.

Zeolit merupakan mineral sekunder alami nanopori dengan luas kontak permukaan yang besar sehingga ideal untuk adsorpsi dan desorpsi nutrien. Zeolit resisten terhadap degradasi biologis dan diharapkan memiliki manfaat jangka panjang untuk daur ulang unsur hara (Weaks et al., 2012). Penambahan zeolit didalam tanah ditujukan untuk meningkatkan $\mathrm{pH}$ tanah karena zeolit bersifat mampu membufer $\mathrm{pH}$ tanah sehingga dapat mendukung pertumbuhan tanaman. Kenaikan $\mathrm{pH}$ umumnya diiringi oleh ketersediaan unsur hara esensial bagi tanaman. Mekanisme yang terjadi akibat adanya pertukaran kation $\mathrm{H}^{+}$dengan kation didalam zeolit. Menurunnya konsentrasi $\mathrm{H}^{+}$dapat meningkatkan $\mathrm{pH}$ tanah. Seiring dengan meningkatnya $\mathrm{pH}$ maka ikatan Al-P dan Fe-P melemah sehingga ketersediaan $\mathrm{P}$ Latosol diharap dapat meningkat. Seiring dengan meningkatnya ketersediaan $\mathrm{P}$ Latosol yang diikuti dengan meningkatnya serapan $\mathrm{P}$ padi gogo. Terjadi penurunan Al yang dapat ditukar dan keasaman tanah yang dapat dititrasi karena kemampuan $\mathrm{CZ}$ (clinoptilolite zeolite) untuk meningkatkan $\mathrm{pH}$ tanah. Meskipun ketersediaan $\mathrm{P}$ tidak signifikan dengan dimasukkannya $\mathrm{CZ}$ dalam studi inkubasi, produksi bahan kering, konsentrasi $\mathrm{P}$, serapan $\mathrm{P}$, dan efisiensi penggunaan $\mathrm{P}$ dalam percobaan pot sebanding dengan pemupukan normal, menunjukkan bahwa $\mathrm{CZ}$ adalah bermanfaat dan dapat digunakan untuk mengurangi kebutuhan pupuk $\mathrm{P}$ untuk budidaya Zea mays L. di tanah masam (Hasbullah et al., 2020).

Berdasarkan hasil penelitian, $\mathrm{P}$ tersedia meningkat pada masing-masing perlakuan kombinasi zeolit dikarenakan zeolit mampu meningkatkan ketersediaan $\mathrm{P}$ dengan mengubah $\mathrm{P}$ tidak tersedia menjadi $\mathrm{P}$ tersedia. Kondisi $\mathrm{P}$ tidak tersedia dikarenakan $\mathrm{P}$ terikat oleh kation-kation tanah sehingga $\mathrm{P}$ menjadi tidak tersedia. Zeolit memiliki muatan negatif yang mampu mengikat kation-kation tanah seperti $\mathrm{Al}$ dan $\mathrm{Fe}$ yang menjadi penyebab fiksasi $\mathrm{P}$ sehingga $\mathrm{P}$ menjadi tersedia dan meningkat.

Penelitian ini bertujuan untuk mengetahui pengaruh dosis zolit dan pupuk SP-36 terhadap ketersediaan P dan serapan P padi Gogo di tanah Latosol.

\section{BAHAN DAN METODE}

Penelitian dilaksanakan bertempat di rumah kaca Fakultas Pertanian Universitas Pembangunan Nasional "Veteran" Yogyakarta. Analisis tanah dan jaringan tanaman dilakukan di Laboratorium Kimia Tanah Fakultas Pertanian, UPN "Veteran" Yogyakarta. Bahan yang digunakan meliputi Latosol, benih padi gogo varietas Situ Bagendit, zeolit, pupuk SP-36 dan Chemikalia untuk analisis laboratorium. Alat yang digunakan meliputi oven, dan alat-alat untuk analisis.

Penelitian dilaksanakan dengan percobaan yang disusun dalam Rancangan Acak lengkap faktorial dengan faktor pertama adalah dosis Zeolit (Sabilu, 2016) terdiri dari $\mathrm{Z}_{0}=0$ ton/ha; $\mathrm{Z}_{1}=2,5$ ton/ha; $\mathrm{Z}_{2}=5$ ton/ha dan faktor kedua adalah dosis pupuk SP-36

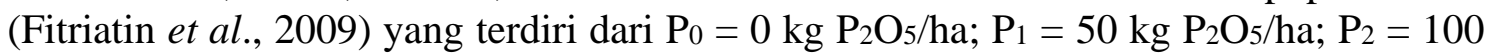
$\mathrm{kg} \mathrm{P}_{2} \mathrm{O}_{5} / \mathrm{ha}$. Sampel tanah yang digunakan adalah Latosol dari Kalibawang Kulon Progo sedangkan Zeolit yang digunakan berasal dari Gedangsari Gunungkidul. Percobaan dilakukan dengan menggunakan pot. Tanah kering angin berdiameter $2 \mathrm{~mm}$ seberat 7 $\mathrm{kg}$ tanah setara kering angin dicampur diberikan pupuk dasar setara $300 \mathrm{~kg} / \mathrm{ha}$ urea dan $50 \mathrm{~kg} / \mathrm{ha} \mathrm{KCl}$. Selanjutnya tanah dicampur dengan Zeolit dan SP-36 sesuai perlakuan 
dan dan diinkubasi selama 30 hari. Setelah masa inkbasi, pot ditanami dengan tanaman padi gogo varietas Situ Bagendit berumur 7 hari dan dipelihara sampai 60 hari setelah tanam. Analisis pendahuluan meliputi $\mathrm{pH} \mathrm{H}_{2} \mathrm{O}, \mathrm{pH} \mathrm{KCl}, \mathrm{C}$-organik, $\mathrm{N}$ total, $\mathrm{P}$ tersedia, $\mathrm{K}$ tersedia, Kapasitas Tukar Kation, Al-dd, Fe-dd dan tekstur untuk sampel tanah; pH $\mathrm{H}_{2} \mathrm{O}$, K total, $\mathrm{Ca}$ total, dan $\mathrm{Na}$ total sampel Zeolit, serta $\mathrm{pH} \mathrm{H}_{2} \mathrm{O}$ untuk sampel pupuk SP-36. Analisis setelah perlakuan meliputi $\mathrm{pH} \mathrm{H}_{2} \mathrm{O}, \mathrm{pH} \mathrm{KCl}, \mathrm{P}$ tersedia, Kapasitas Tukar Kation sampel tanah dan berat kering tanaman dan kadar $\mathrm{P}$ jaringan untuk menghitung serapan P. Data sifat kimia tanah dan jaringan tanaman dianalisis keragamannya, apabila terdapat beda nyata dilakukan uji pembandingan rerata perlakuan dengan uji jarak berganda Duncans Multiple Range Test (DMRT) dengan taraf $5 \%$.

\section{HASIL DAN PEMBAHASAN}

\section{Analisis Pendahuluan}

Sebelum dilakukan percobaan, semua bahan dianalisis terlebih dahulu untuk mengetahui karakteristik bahan yang digunakan. Hasil analisis sifat kimia Latosol, Zeolit, dan pupuk SP-36 yang digunakan tersaji dalam Tabel 1.

Tabel 1. Hasil analisis sifat kimia tanah latosol, pupuk SP-36 dan Zeolit yang digunakan.

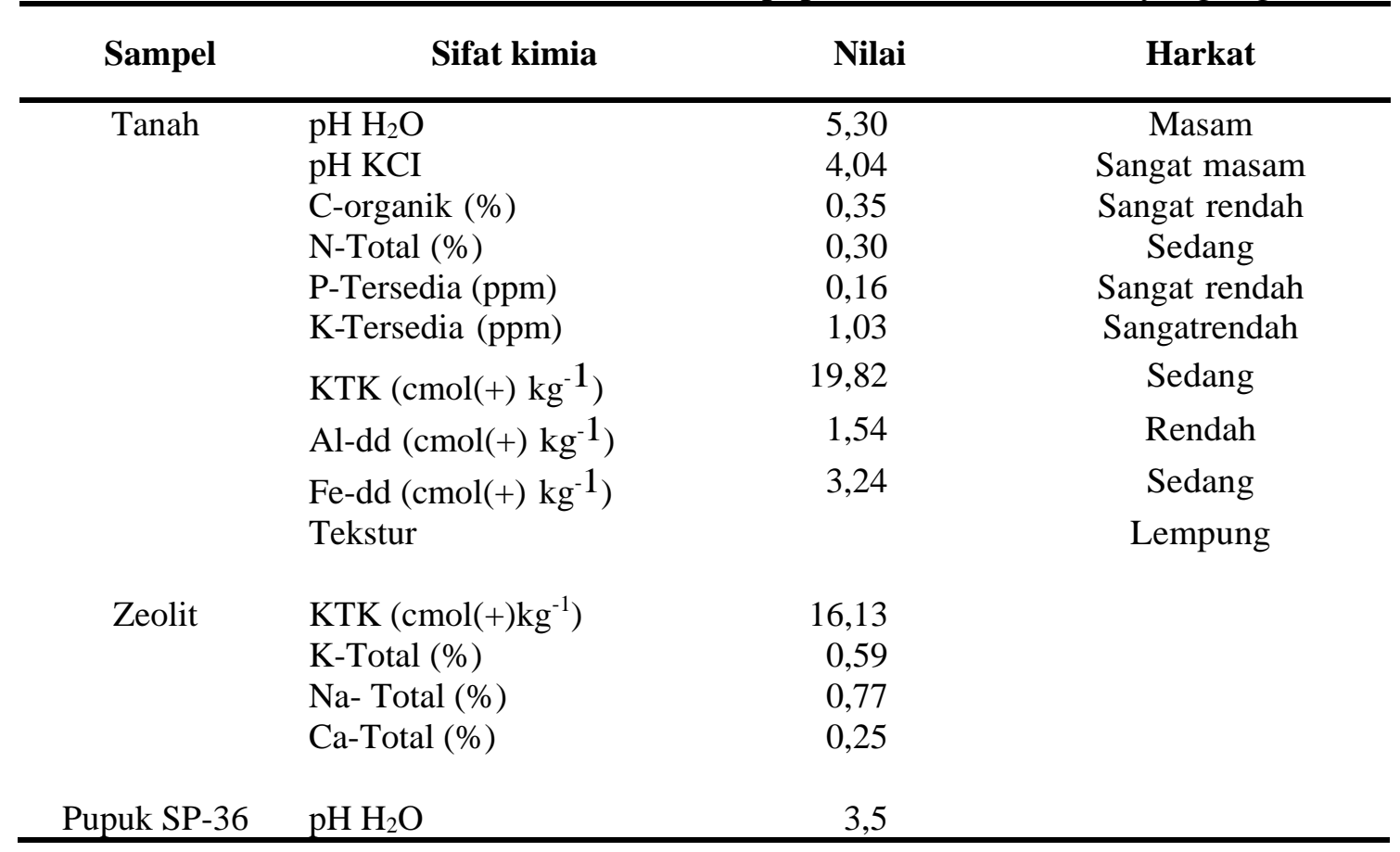

Dari hasil analisis $\mathrm{pH}$ tanah latosol termasuk berharkat masam. Menurut Soepraptohardjo (1961) hal ini dikarenakan Latosol merupakan tanah yang telah mengalami pelapukan lanjut dan mengalami proses pencucian sehingga kation-kation basa dalam koloid tanah banyak yang telah hilang. Hasil analisis menunjukkan bahwa $\mathrm{pH} \mathrm{KCl}$ mempunyai nilai yang lebih rendah dibandingkan dengan $\mathrm{pH} \mathrm{H}_{2} \mathrm{O}$. Hal ini menunjukkan bahwa muatan tanah didominasi muatan negatif. 
Hasil analisis C-Organik menunjukkan harkat sangat rendah, hal ini diduga dikarena tidak ada penambahan bahan organik dari sisa tanaman maupun pupuk organik pada areal pengambilan sampel tanah. Rendahnya kadar bahan organik pada tanah Latosol yang digunakan akan mempengaruhi aktivitas mikroorganisme yang pada akhirnya akan mempengaruhi proses perubahan sifat kimia tanah. Rendahnya kandungan bahan organik telah menyebabkan proses degradasi lahan dan menurunkan produktivitas lahan pertanian.

Nitrogen-total Latosol menunjukkan harkat sedang. Hal ini dapat diartikan di dalam tanah memiliki unsur $\mathrm{N}$ yang cukup untuk dimanfaatkan tanaman. Ketersediaan $\mathrm{N}$ dalam tanah juga dipengaruhi proses proses dekomposisi bahan organik, nitrifikasi dan denitrifikasi. Nitrogen dalam bentuk $\mathrm{NH}_{4}{ }^{+}$dimungkinkan terikat dalam komplek jerapan KPK pada tanah latosol. P-tersedia Latosol menunjukkan harkat sangat rendah, hal ini dapat diakibatkan diikat oleh logam $\mathrm{Al}$ dan $\mathrm{Fe}$ yang mengakibatkan $\mathrm{P}$ rnenjadi tidak tersedia bagi tanaman. Analisis K-Tersedia Latosol menunjukkan harkat sangat rendah. Rendahnya kadar $\mathrm{K}$ tersedia dapat diakibatkan karena proses pelindihan akibat faktor iklim dan waktu dalam proses pembentukan tanah. Dari hasil analisis KTK diperoleh 19,82 $\mathrm{cmol}(+) \mathrm{kg}^{-1}$ dengan harkat sedang. KTK dipengaruhi oleh jenis lempung dan bahan organik. Besarnya KTK dalam tanah dipengaruhi jenis dan kadar lempung serta kadar bahan organik. 1:1 cenderung mempunyai nilai KTK yang rendah dan bahan organik yang tinggi dapat mendukung KTK tanah yang tinggi. Walaupun Latosol ini memiliki tekstur lempung namun karena lempung berjenis kaolinit (Hardjowigeno, 2010) maka KTK menjadi rendah. Hal ini ditambah lagi dengan kandungan bahan organik yang sangat rendah sehingga KTK didominasi muatan yang berasal dari lempung. Hasil analisis Al-dd dan Fe-dd menunjukkan keberadaan unsur yang dapat menjerap $\mathrm{P}$ didalam tanah sehingga membuat P-tersedia Latosol rendah. Unsur tersebut dianggap berpengaruh terhadap ketersediaan $\mathrm{P}$ tanah yang perlu diatasi untuk mendukung pertumbuhan tanaman.

Hasil analisis zeolit menunjukkan KTK sebesar $16,13 \mathrm{cmol}(+) \mathrm{kg}^{-1}$. Menurut Ardiana dan Budianta (2019), hasil pengujian KTK zeolit Gedangsari menunjukkan nilai KTK sebesar $102,8 \mathrm{cmol}(+) \mathrm{kg}^{-1}$. KTK yang tinggi pada sampel dipengaruhi oleh mineral zeolit dan pada tingkat pertukaran yang rendah oleh mineral mikro. KTK juga dipengaruhi oleh struktur zeolit dan ukuran yang kecil sehingga daya singgung menjadi besar sehingga dapat berkontak dengan tanah dengan baik. Zeolit yang dapat digunakan untuk pembenah tanah memiliki KTK minimal $80 \mathrm{cmol}(+) \mathrm{kg}^{-1}$. Kandungan K-Total sebesar 0,59\%, Na-total sebesar 0,77\% dan Ca total sebesar 0,25\% yang diharapkan mampu meningkatkan kandungan unsur hara di dalam tanah guna mendukung produksi tanaman. Reaksi $(\mathrm{pH})$ zeolit yang menunjukkan nilai diatas netral dianggap mampu meningkatkan $\mathrm{pH}$ tanah dengan kation basa yang dimilikinya. Pupuk SP-36 memiliki $\mathrm{pH}$ yang masam merupakan akibat proses pembuatannya yang mengandung asam ortofosfat.

\section{Analisis Setelah Perlakuan}

\section{Reaksi Tanah (pH)}

Reaksi tanah $(\mathrm{pH})$ merupakan sifat kimia tanah yang sangat penting karena berpengaruh terhadap tingkat ketersediaan unsur hara di dalam tanah. Dari hasil sidik ragam menunjukkan bahwa dosis zeolit berpengaruh nyata sedangkan perlakuan dosis pupuk SP 36 tidak berpengaruh nyata terhadap perubahan $\mathrm{pH}$ tanah 
latosol. Tidak terdapat interaksi antara kedua perlakuan tersebut. Hasil rerata $\mathrm{pH}$ $\mathrm{H}_{2} \mathrm{O}$ tanah pada berbagai kombinasi perlakuan tersaji dalam tabel 2. Peningkatan maupun penurunan $\mathrm{pH}$ dapat dipengaruhi oleh penambahan zeolit. Semakin banyak pemberian zeolit maka kandungan logam alkali semakin tinggi sehingga dapat meningkatkan $\mathrm{pH}$ tanah.

Pemberian zeolit mampu meningkatkan $\mathrm{pH} \mathrm{H}_{2} \mathrm{O}$ Latosol sejalan dengan meningkatnya dosis yang diberikan. Pemberian zeolit 2,5 ton/ha $\left(\mathrm{Z}_{1}\right)$ memiliki nilai $\mathrm{pH} \mathrm{H}_{2} \mathrm{O}$ yang lebih tinggi daripada tanpa pemberian zeolit 0 ton/ha $\left(\mathrm{Z}_{0}\right)$, namun tidak berbeda nyata dengan pemberian zeolit 5 ton/ha $\left(\mathrm{Z}_{2}\right)$. Menurut Aainaa et al., (2018) mekanisme yang terjadi akibat koloid tanah melepaskan ion $\mathrm{H}^{+}$yang mampu melepaskan kation zeolit.

Tabel 2. Rerata $\mathrm{pH} \mathrm{H}_{2} \mathrm{O}$ pada berbagai kombinasi perlakuan zeolit dan SP-36.

\begin{tabular}{ccccc}
\hline \multirow{2}{*}{ Dosis Zeolit } & \multicolumn{3}{c}{ Dosis pupuk SP-36 } & \multirow{2}{*}{ Rerata } \\
\cline { 2 - 4 } & $\mathbf{P}_{\mathbf{1}}$ & $\mathbf{P}_{\mathbf{2}}$ & $\mathbf{P}_{\mathbf{3}}$ & \\
\hline $\mathrm{Z}_{0}$ & 5,40 & 5,63 & 5,63 & $5,5 \mathrm{~b}$ \\
$\mathrm{Z}_{1}$ & 6,13 & 6,47 & 6,50 & $6,37 \mathrm{a}$ \\
$\mathrm{Z}_{2}$ & 6,30 & 6,17 & 6,13 & $6,2 \mathrm{a}$ \\
Rerata & $5,94 \mathrm{p}$ & $6,09 \mathrm{p}$ & $6,09 \mathrm{p}$ & $(-)$ \\
\hline
\end{tabular}

Keterangan: Angka pada kolom dan baris yang diikuti oleh huruf yang sama tidak menunjukkan beda nyata berdasarkan uji DMRT taraf 5\%. Tanda (-) menunjukkan tidak ada interaksi antar perlakuan berbagai kombinasi perlakuan tersaji dalam tabel 2 .

Keberadaan logam alkali seperti $\mathrm{Ca}^{2+}$ dan $\mathrm{Na}^{+}$pada koloid tanah akan berakibat $\mathrm{pH}$ tanah meningkat. Aplikasi SP-36 tidak menunjukkan pengaruh nyata pada $\mathrm{pH} \mathrm{H}_{2} \mathrm{O}$ Latosol, namun terdapat peningkatan $\mathrm{pH}$ Latosol pada pemberian dosis SP-36 ( $\mathrm{P}_{1}$ dan $\left.\mathrm{P}_{2}\right)$ dibandingkan tanpa SP-36 (P0). Menurut Ramesh et al. (2015) zeolit yang memiliki $\mathrm{pH}$ mendekati netral dapat mempengaruhi $\mathrm{pH}$ tanah masam. Kemampuan mempertukarkan kation $\mathrm{Na}+$ dan $\mathrm{K}+$ dengan $\mathrm{H}+$ yang menjadikan $\mathrm{pH}$ tanah Latosol dapat meningkat.

\section{Kapasitas Tukar Kation}

Salah parameter penentu kesuburan tanah adalah kemampuan tanah dalam menyimpan unsur hara adalah besarnya Kapasitas Tukar Kation (KTK). Tanah yang memiliki KTK tinggi mampu menyimpan unsur hara lebih banyak. Hasil sidik ragam KTK tanah pada berbagai kombinasi perlakuan dosis zeolit dan dosis SP-36 menunjukkan bahwa perlakuan dosis zeolit maupun perlakuan dosis SP-36 tidak berpengaruh nyata terhadap KPK tanah. Tidak ada interaksi antar perlakuan dosis zeolit dan dosis SP-36. Rerata KTK tanah pada berbagai kombinasi perlakuan dosis zeolit dan dosis SP-36 tersaji dalam Tabel 3.

Dari Tabel 3. menunjukkan bahwa KTK tanah meningkat sejalan dengan meningkatnya zeolit yang diberikan. Kecilnya kenaikan KTK akibat perlakuan zeolit diduga diakibatkan karena ukuran zeolit yang masih terlalu besar dan KTK zeolit yang hanya $16,13 \mathrm{Cmol}(+) \cdot \mathrm{kg}^{-1}$. Nilai KTK dipengaruhi oleh ukuran dan jenis zeolit. Semakin kecil ukuran zeolit semakin luas permukaannya sehingga nilai KTK menjadi semakin besar. Perlakuan dosis SP-36 juga tidak berpengaruh 
terhadap perubahan KTK tanah. Hal ini disebabkan karena pupuk SP-36 tidak menimbulkan perubahan $\mathrm{pH}$ yang dapat mempengaruhi KTK tanah.

\section{P-tersedia}

Unsur P didalam tanah umumnya dipengaruhi oleh tingkat kemasaman tanah yang menyebabkan $\mathrm{P}$ menjadi tersedia dalam jumlah yang cukup bagi tanaman atau menjadi tidak tersedia bagi tanaman karena dijerap oleh unsur lain didalam tanah. Dari hasil sidik ragam menunjukkan bahwa terdapat interaksi perlakuan dosis Zeolit dan dosis pupuk SP-36. Berdasarkan Tabel 3. menunjukkan bahwa dosis zeolit dan SP-36 yang dapat meningkatkan P-tersedia. Pada perlakuan kombinasi $\mathrm{Z}_{1} \mathrm{P}_{1}$ memiliki kadar P-tersedia tanah tertinggi dan pada kombinasi zeolit tanpa zeolit dan SP-36 $\left(\mathrm{Z}_{0} \mathrm{P}_{0}\right)$ memiliki kadar P-tersedia tanah terendah. Hal ini diduga pada perlakuan $\mathrm{Z}_{1} \mathrm{P}_{1}$ terjadi pengaruh penambahan Zeolit yang cenderung meningkatkan meningkatkan $\mathrm{pH}$ ta nah karena terdapat kandungan $\mathrm{Ca}$ yang terdapat didalamnya sebaliknya walaupun penambahan SP-36 berpengaruh meningkatkan $\mathrm{pH}$ tanah namun pupuk SP-36 sendiri bersifat masam sehingga saat diberikan bersamaan akan meningkatkan $\mathrm{P}$ tersedia dalam tanah.

Pemberian pupuk SP-36 merupakan nutrisi tambahan dan tidak sebagai bahan pembenah tanah. Berdasarkan dari kandungannya, pupuk SP-36 yang memiliki rumus kima $\mathrm{Ca}\left(\mathrm{H}_{2} \mathrm{PO}_{4}\right)_{2}$ memiliki unsur $\mathrm{Ca}$ yang mampu meningkatkan $\mathrm{pH} \mathrm{H}_{2} \mathrm{O}$. $\mathrm{Ca}$ dari pupuk terlepas dan menjenuhi tanah sehingga $\mathrm{pH}$ naik. Namun apliaksi SP36 yang terlalu dengan dosis yang terlalu tinggi menimbulkan dampak lain, kandungan asam fosfat dalam proses pembuatannya dapat mempengaruhi kemasaman tanah.

Tabel 3. Rerata P-tersedia Latosol ( $\mathrm{ppm})$ pada berbagai kombinasi perlakuan zeolit dan SP-36.

\begin{tabular}{ccccc}
\hline \multirow{2}{*}{ Dosis Zeolit } & \multicolumn{3}{c}{ Dosis pupuk SP-36 } & \multirow{2}{*}{ Rerata } \\
\cline { 2 - 4 } & $\mathbf{P}_{\mathbf{1}}$ & $\mathbf{P}_{\mathbf{2}}$ & $\mathbf{P}_{\mathbf{3}}$ & \\
\hline $\mathrm{Z}_{0}$ & $1,67 \mathrm{e}$ & $2,91 \mathrm{~d}$ & $4,43 \mathrm{~b}$ & 3,00 \\
$\mathrm{Z}_{1}$ & $2,66 \mathrm{~d}$ & $5,31 \mathrm{a}$ & $3,76 \mathrm{bc}$ & 3,91 \\
$\mathrm{Z}_{2}$ & $3,86 \mathrm{bc}$ & $3,49 \mathrm{~cd}$ & $3,76 \mathrm{bc}$ & 3,70 \\
Rerata & 2,73 & 3,90 & 3,98 & $(+)$ \\
\hline
\end{tabular}

Keterangan: Angka pada kolom dan baris yang diikuti oleh huruf yang sama tidak menunjukkan beda nyata, berdasarkan uji DMRT taraf 5\%. Tanda (+) menunjukkan ada interaksi antar perlakuan

Pemberian zeolit juga dapat mengurangi daya fiksasi $\mathrm{P}$ oleh ion-ion logam $\mathrm{Al}$ dan $\mathrm{Fe}$, karena zeolit memiliki struktur yang tersusun atas unit-unit tetrahedral ( $\left.\mathrm{SiO}_{4}\right)-4$ yang berikatan oleh atom oksigen sehingga menyababkan zeolit kelebihan satu muatan negatif yang diseimbangkan oleh kation $\mathrm{Al}$ dan $\mathrm{Fe}$ sehingga zeolit mampu mengurangi daya fiksasi $\mathrm{P}$ terhadap kation $\mathrm{Al}$ dan $\mathrm{Fe}$ (Syamsiah et al., 2009).

Struktur kerangka zeolit tersusun atas unit-unit tetrahedral (AlO4)-5 dan (SiO4)-4 yang saling berikatan melalui atom oksigen membentuk pori-pori zeolit. Ion silikon bervalensi 4, sedangkan aluminium bervalensi 3. Hal ini menyebabkan struktur zeolit kelebihan muatan negatif yang diseimbangkan oleh kation-kation 
seperti Fe dan Al. Zeolit dapat mengubah $\mathrm{P}$ tidak tersedia menjadi $\mathrm{P}$ tersedia dengan mengurangi daya fiksasi $\mathrm{P}$ terhadap kation $\mathrm{Fe}$ dan $\mathrm{Al}$, sehingga serapan hara pada tanaman meningkat (Arafat et al., 2016).

Latosol memiliki kisaran $\mathrm{pH}$ agak masam yang menunjukkan unsur-unsur yang mendominasi adalah unsur logam seperti $\mathrm{Al}$ dan $\mathrm{Fe}$, sehingga fiksasi $\mathrm{P}$ oleh logam-logam ini sangat sulit untuk dilepas. Proses ini erat kaitanya dengan $\mathrm{pH}$ tanah, dibuktikan dengan analisis koefisien korelasi yang menunjukkan nilai $\mathrm{r}=$ 0,57 . Semakin tinggi nilai $\mathrm{pH}$ tanah maka P-tersedia meningkat. Hal ini dapat diketahui dari nilai $\mathrm{pH} \mathrm{H}_{2} \mathrm{O}$ tanah yang telah dilakukan.

\section{Kadar P jaringan.}

Kadar unsur dalam jaringan tanaman merupakan gambaran dari tingkat kecukupan hara suatu tanaman. Tanaman membutuhkan unsur hara yang jumlah yang cukup untuk dapat menghasilkan produksi yang optimal. Analisis jaringan tanaman dapat memberikan informasi tentang status nutrisi tanaman saat ini dan membantu dalam memverifikasi diagnosis visual gejala defisiensi / toksisitas.

Hasil sidik ragam menunjukkan bahwa terdapat interaksi antara perlakuan dosis Zeolit dan dosis SP-36. Dari tabel 4. pada perlakuan kombinasi $\mathrm{Z}_{2} \mathrm{P}_{2}$ memiliki kadar P-jaringan tertinggi dan tidak berbeda nyata dengan kombinasi $\mathrm{Z}_{2} \mathrm{P}_{3}$. Pada kombinasi $\mathrm{Z}_{0} \mathrm{P}_{1}$ memiliki kadar $\mathrm{P}$-jaringan terendah namun tidak berbeda nyata dengan beberapa kombinasi zeolit dan SP-36 $\left(\mathrm{Z}_{0} \mathrm{P}_{0}, \mathrm{Z}_{0} \mathrm{P}_{2}, \mathrm{Z}_{1} \mathrm{P}_{0}, \mathrm{Z}_{1} \mathrm{P}_{1}, \mathrm{Z}_{1} \mathrm{P}_{2}\right.$ dan $\mathrm{Z}_{2} \mathrm{P}_{0}$ ).

Tabel 4. Rerata P jaringan padi gogo pada perlakuan zeolit dan SP-36 (mg/tanaman).

\begin{tabular}{ccccc}
\hline \multirow{2}{*}{ Dosis Zeolit } & \multicolumn{3}{c}{ Dosis pupuk SP-36 } & \multirow{2}{*}{ Rerata } \\
\cline { 2 - 4 } & $\mathbf{P}_{\mathbf{1}}$ & $\mathbf{P}_{\mathbf{2}}$ & $\mathbf{P}_{\mathbf{3}}$ & \\
\hline $\mathrm{Z}_{0}$ & $0,32 \mathrm{~cd}$ & $0,29 \mathrm{~cd}$ & $0,37 \mathrm{bc}$ & 0,33 \\
$\mathrm{Z}_{1}$ & $0,36 \mathrm{bc}$ & $0,32 \mathrm{~cd}$ & $0,35 \mathrm{bc}$ & 0,34 \\
$\mathrm{Z}_{2}$ & $0,35 \mathrm{bc}$ & $0,43 \mathrm{a}$ & $0,39 \mathrm{ab}$ & 0,39 \\
Rerata & 0,34 & 0,35 & 0,37 & $(+)$ \\
\hline
\end{tabular}

Keterangan: Angka pada kolom dan baris yang diikuti oleh huruf yang sama tidak menunjukkan beda nyata, berdasarkan uji DMRT taraf 5\%. Tanda $(+)$ menunjukkan ada interaksi antar perlakuan

Kadar unsur dalam jaringan tergantung pada kadar unsur hara dalam tanah. Kadar $\mathrm{P}$ pada semua unit percobaan berada pada kisaran optimum. Menurut Dobermann dan Fairhurst, (2000) kandungan P optimal dalam jaringan tanaman padi berkisar pada $0,20-0,40 \%$ berat kering jaringan pada masa vegetatif maksimum. Perlakuan zeolit yang dikombinasikan dengan pupuk SP-36 mampu meningkatkan kadar $\mathrm{P}$ dalam jaringan tanaman padi gogo. Zeolit mempunyai muatan negatif sehingga mampu mengikat unsur unsur-unsur yang bermuatan positif seperti $\mathrm{Al}, \mathrm{Fe}$ dan $\mathrm{Mn}$ di dalam tanah melalui mekanisme pertukaran kation. Dengan terikatnya unsur, $\mathrm{Al}, \mathrm{Fe}$ dan $\mathrm{Mn}$, akan mengurangi terjadinya fiksasi unsur $\mathrm{P}$, sehingga terjadi peningkatan $\mathrm{P}$ tersedia tanah. Selain itu, penambahan pupuk SP36 juga akan meningkatkan kadar $\mathrm{P}$ tersedia dalam tanah. Adanya peningkatan $\mathrm{pH}$ tanah akibat penambahan zeolit juga akan berpengaruh pada tingkat kelarutan $\mathrm{P}$ dalam tanah Latosol. Hasil penelitian Arafat et al., (2016) menunjukkan bahwa 
zeolit berpengaruh terhadap efisiensi pemupukan P. Pemberian zeolit 9,3 ton.ha ${ }^{-}$ ${ }^{1}$ dengan kombinasi pupuk SP-36 $150 \mathrm{~kg} \mathrm{ha}^{-1}$ mampu meningkatkan efisiensi pemupukan P sebesar $65 \%$.

\section{Serapan $\mathbf{P}$}

Serapan $\mathrm{P}$ jaringan tanaman merupakan jumlah unsur hara $\mathrm{P}$ yang diserap oleh tanaman. Serapan unsur hara dipengaruhi oleh berat kering tanaman dan kadar hara dalam jaringan. Hasil sidik ragam menunjukkan bahwa perlakuan dosis zeolit maupun perlakuan dosis pupuk SP-36 tidak berpengaruh nyata terhadap serapan hara P tanaman padi gogo Situbagendit. Tidak ada interaksi antar kedua perlakuan dosis zeolit dan dosis SP-36. Rerata serapan P padi gogo Situbagendit pada berbagai kombinasi perlakuan dosis zeolit dan dosis SP-36 tersaji dalam Tabel 5.

Perlakuan zeolit 5 ton/ha $\left(\mathrm{Z}_{2}\right)$ menghasilkan serapan $\mathrm{P}$ terbaik namun tidak berbeda nyata dengan aplikasi zeolit 0 ton/ha $\left(Z_{0}\right)$ dan zeolit 2,5 ton/ha $\left(Z_{1}\right)$. Perlakuan SP-36 dengan dosis $138,89 \mathrm{~kg} / \mathrm{ha}\left(\mathrm{P}_{2}\right)$ menghasilkan tanaman terbaik dibandingkan dengan dosis SP-36 yang lain. Serapan P meningkat seiring dengan penambahan dosis pupuk SP-36 dan zeolit yang diberikan. Hal ini diduga berkaitan dengan terjadinya kenaikan P tersedia dalam tanah akibat zeolit dan pupuk SP-36 yang diberikan. Peningkatan $\mathrm{P}$ tersedia dalam tanah akan mempengaruhi kadar unsur hara di dalam jaringan tanaman. Serapan $\mathrm{P}$ oleh tanaman meningkat dengan meningkatnya kadar $\mathrm{P}$ pada jaringan tanaman. Besarnya serapan $\mathrm{P}$ pada tanaman tergantung pada besarnya ketersediaan P didalam tanah (Basyaruddin, 2001). Hasil kajian uji efektivitas zeolit pada kondisi di rumah kaca menunjukkan bahwa pemberian pembenah tanah zeolit dapat meningkatkan hasil gabah bernas sekitar $19,41 \%$ dimana rata-rata bobot gabah padi bernas tanpa zeolit adalah 61,22 gram/pot, sedangkan dengan zeolit adalah 73,30 gram/pot (Al-Jabri, 2010).

Tabel 5. Rerata serapan P padi gogo pada berbagai kombinasi perlakuan dosis zeolit dan dosis SP-36 (mg/tanaman).

\begin{tabular}{ccccc}
\hline \multirow{2}{*}{ Dosis Zeolit } & \multicolumn{3}{c}{ Dosis pupuk SP-36 } & \multirow{2}{*}{ Rerata } \\
\cline { 2 - 4 } & $\mathbf{P}_{\mathbf{1}}$ & $\mathbf{P}_{\mathbf{2}}$ & $\mathbf{P}_{\mathbf{3}}$ & \\
\hline $\mathrm{Z}_{0}$ & 8,65 & 8,67 & 10,32 & $9,22 \mathrm{a}$ \\
$\mathrm{Z}_{1}$ & 6,90 & 8,72 & 7,71 & $7,78 \mathrm{a}$ \\
$\mathrm{Z}_{2}$ & 9,98 & 14,85 & 11,49 & $12,11 \mathrm{a}$ \\
Rerata & $8,51 \mathrm{p}$ & $10,75 \mathrm{p}$ & $9,84 \mathrm{p}$ & $(-)$ \\
\hline
\end{tabular}

Keterangan: Angka pada kolom dan baris yang diikuti oleh huruf yang sama tidak menunjukkan beda nyata berdasarkan uji DMRT taraf 5\%. Tanda (-) menunjukkan tidak ada interaksi antar perlakuan.

\section{KESIMPULAN}

Hasil penelitian menunjukkan bahwa perlakuan dosis zeolit berpengaruh nyata terhadap $\mathrm{pH} \mathrm{H}_{2} \mathrm{O}$, P-tersedia Latosol dan P-jaringan, tetapi tidak berpengaruh nyata terhadap serapan $\mathrm{P}$ padi gogo Situbagendit. Perlakuan dosis SP-36 berpengaruh nyata terhadap P-tersedia, tetapi tidak berpengaruh nyata terhadap $\mathrm{pH} \mathrm{H}_{2} \mathrm{O}$ Latosol, P-jaringan dan serapan P padi gogo. Terdapat interaksi dosis zeolit dan dosis SP-36 yang nyata meningkatkan P-tersedia dan P-jaringan. Zeolit setara 5 ton/ha dan SP-36 setara $50 \mathrm{~kg}$ 
$\mathrm{P}_{2} \mathrm{O}_{5}$ merupakan dosis optimal untuk meningkatkan pertumbuhan padi gogo di Latosol.

\section{DAFTAR PUSTAKA}

Aainaa, H. N., Osumanu, H. A., Nik, M. A. M., 2018. Effects of clinoptilolite zeolite on phosphorus dynamics and yield of Zea Mays L. cultivated on an acid soil. PLOS ONE | https://doi.org/10.1371/journal.pone.0204401 September 27, 2018.

A'isyah, T P Napitupulu, dan I M Sudiana. 2019 Effect of zeolite particle size and levels of phosphate concentration in phosphate absorption and growth of Sorghum bicolor (L.) Moench. IOP Conf. Ser.: Earth Environ. Sci. 308012044

Al-Jabri, M. 2010. Penggunaan Mineral Zeolit Sebagai Pembenah Tanah Pertanian Dalam Hubungan Dengan Standardisasinya dan Peningkatan Produksi Tanaman Pangan Jurnal Zeolit Indonesia Vol 9 No. 1.

Arafat, Y., N. Kusumarini, Syekhfani. 2016. Pengaruh Pemberian Zeolit Terhadap Efisiensi Pemupukan Fosfor Dan Pertumbuhan Jagung Manis Di Pasuruan, Jawa Timur. Jurnal Tanah dan Sumberdaya Lahan Vol 3 No 1: 319-327, 2016. http://jtsl.ub.ac.id

Basyaruddin. 2001. Pengaruh residu pemupukan P pada beberapa famili Andisols terhadap pertumbuhan, hasil, serapan $\mathrm{P}$ dan $\mathrm{Cl}$ tembakau Deli di Sumatra Utara. Jurnal Agrista 6 (1), 50-55.

Darmawidjaja, M. I. 1990. Klasifikasi Tanah. Yogyakarta: Gadjah Mada University Press,

Dobermann, A dan T. H. Fairhurst. 2000. Rice: Nutrient Disorder \& Nutrient Management. Handbook Series. Potash \& Phosphate Institute (PPI), Potash \& Phosphate Institute of Canada (PPIC) and International Rice Research Institute (IRRI).

Fitriatin, Betty N., Yuniarti, Anny, Mulyani, Oviyanti, Fauziah, F. S., Tiara, M. D. 2009. Tersedia, Aktivitas Fosfatase, Populasi Mikroorganisme Pelarut Fosfat, Konsentrasi P Tanaman dan Hasil Padi Gogo (Oryza sativa. L.) pada Ultisols. Jurnal Agrikultura, Vol. 20, No 3.

Hasbullah, N. A., O. H. Ahmed and N. M. Ab Majid. 2020. Effects of Amending Phosphatic Fertilizers with Clinoptilolite Zeolite on Phosphorus Availability and Its Fractionation in an Acid Soil. Appl. Sci., 10, 3162

Ramesh, V., George, J., Jyothi J.S., and Shibli, S.M.A. Effect of Zeolites on Soil Quality, Plant Growth and Nutrient Uptake Efficiency in Sweet Potato (Ipomoea batatas L.). Journal of Root Crops, 2015, Vol. 41 No. 1, pp. 25-31.

Rismunandar. 1990. Budidaya dan Tataniaga Pala. Cetakan kedua. Jakarta: Penebar Swadaya.

Sabilu, Y. 2016. Aplikasi Zeolit Meningkatkan Hasil Tanaman Pada Tanah Ultisol. Biowallacea, Vol. 3 (2), Hal: 396-407, Oktober, 2016.

Weaks, E. N., Y. Raut, H. Jahan, and K. R. Islam. Zeolite Effects on Nitrogen and Phosphorus Availability in Soil. Soil, Water and Bioenergy Resources, Ohio State University South Centers, Piketon [diakses 20 Januari 2020; 20.30 WIB. 